\title{
Serum histidine in rheumatoid arthritis: a family study
}

\author{
J. KIRKHAM, J. LOWE, H. A. BIRD, AND V. WRIGHT
}

From the Clinical Pharmacology Unit, Royal Bath Hospital, Harrogate

SUMMARY We have compared free serum histidine in patients with rheumatoid arthritis, their blood relatives, and their non-blood relatives. The hypohistidinaemia of rheumatoid arthritis is acquired with the disease and does not provide a biochemical marker of those at risk.

Free serum histidine levels are low in rheumatoid arthritis, a finding that appears to be unique to this disease. ${ }^{1}$ Genetic factors, mediated by histocompatibility antigens, have been shown to be important in rheumatoid arthritis, ${ }^{2}$ and since amino acid levels in the blood may also be determined genetically ${ }^{3}$ it remains a possibility that a low serum histidine might be of value as a marker for determining those persons at risk of developing rheumatoid arthritis. The significantly lower serum histidine found in normal females $^{4}$ than in normal males supports this hypothesis, since rheumatoid arthritis is also more common in females.

We have therefore compared free serum histidine in patients with rheumatoid arthritis, their blood relatives, and their non-blood relatives, who acted as a control group. We have also examined the relationship of serum histidine to seropositivity for rheumatoid factor.

\section{Subjects and methods}

There were 28 patients with classical or definite rheumatoid arthritis (ARA criteria) and 29 blood relatives of whom 2 were sisters, 2 brothers, 9 daughters, 10 sons, 1 a mother, 2 nieces, 1 a nephew, and 2 grand-daughters. Seventeen non-blood relatives formed a control group of whom 13 were spouses, 1 a sister-in-law, 2 daughters-in-law, and 1 a son-inlaw. A medical history was taken from each subject and rheumatoid factor (latex slide test and sheep cell agglutination test) measured. A clotted blood sample was taken and serum separated within 4 hours and frozen to $-20^{\circ} \mathrm{C}$. Histidine levels were measured by a spectrofluorometric method. ${ }^{5}$ Student's $t$ test was applied to the results.

In a further study of 79 patients with peripheral

Accepted for publication 6 November 1980.

Correspondence to Dr H. A. Bird, Clinical Pharmacology Unit, Royal Bath Hospital, Cornwall Road, Harrogate HG1 2PS. polyarthritis of rheumatoid type as defined by the criteria of the American Rheumatism Association the relationship between serum histidine and rheumatoid factor was investigated.

\section{Results}

The mean free serum histidine was significantly lower in the rheumatoid patients than in their nonblood relatives who acted as controls (Table 1).

The mean free serum histidine of the blood relatives of rheumatoid patients did not differ significantly from that of the non-blood relatives. All blood relatives and non-blood relatives were seronegative for rheumatoid factor, and none gave a history of rheumatoid arthritis.

In the subsequent study in which the mean serum histidine was measured in 79 patients with peripheral polyarthritis 49 patients positive for circulating rheumatoid factor had a mean histidine of $1 \cdot 18$ $(\mathrm{SD}=0 \cdot 26$, while 30 patients with seronegative polyarthritis had a mean histidine of $1 \cdot 32$ (SD = $0 \cdot 30$ ).

\section{Discussion}

We found no significant degree of hypohistidinaemia

Table 1 Free serum histidine levels in 3 groups of subjects

\begin{tabular}{|c|c|c|c|}
\hline & $\begin{array}{l}\text { Rheumatoid } \\
\text { arthritis }\end{array}$ & $\begin{array}{l}\text { Blood } \\
\text { relatives }\end{array}$ & $\begin{array}{l}\text { Non-blood } \\
\text { relatives } \\
\text { (control group) }\end{array}$ \\
\hline No. of subjects & $\begin{array}{l}28 \mathrm{M} / \mathrm{F}= \\
10 / 18\end{array}$ & $\begin{array}{l}29 M / F= \\
13 / 16\end{array}$ & $\begin{array}{l}17 \mathrm{M} / \mathrm{F}= \\
8 / 9\end{array}$ \\
\hline $\begin{array}{l}\text { Serum histidine } \\
\text { (mgms } / 100 \mathrm{ml}) \\
\text { mean } \pm \text { standard } \\
\text { deviation }\end{array}$ & $\begin{array}{l}1 \cdot 23( \pm 0 \cdot 19) \\
M / F=1 \cdot 17 / \\
1 \cdot 33\end{array}$ & $\begin{array}{l}1.45( \pm 0.20) \\
M / F=1 \cdot 48 / \\
1 \cdot 41\end{array}$ & $\begin{array}{l}1 \cdot 47( \pm 0 \cdot 22) \\
M / F=1 \cdot 56 / \\
1 \cdot 39\end{array}$ \\
\hline $\begin{array}{l}\text { Latex fixation test } \\
\text { Level of } \\
\text { significance } \\
\text { compared with } \\
\text { control }\end{array}$ & All positive & All negative & All negative \\
\hline
\end{tabular}


in the fit blood relatives of patients suffering from rheumatoid arthritis. The hypohistidinaemia is a direct consequence of acquired rheumatoid arthritis rather than an inherited trait that might act as a marker for susceptible individuals. The subsequent finding that the hypohistidinaemia is less marked in patients with seronegative polyarthritis than in seropositive patients confirms that the abnormality is a consequence of the disease, apparently associated with seropositivity rather than mere inflammation of the synovium.

We thank Dr M. E. Pickup and Mr J. Dixon for expert technical assistance and advice and Mrs J. Battersby for typing the script. The Clinical Pharmacology Unit acknowledges the financial support of Roche Products Ltd.

\section{References}

1 Gerber D A. Low free serum histidine concentration in rheumatoid arthritis. J Clin Invest 1975 ; 55: 1164-71.

2 Panayi G S, Wooley P, Batchelor J R. Genetic basis of rheumatoid disease; HLA antigens, disease manifestations and toxic reactions to drugs. $\mathrm{Br} \mathrm{Med} J 1978$; ii: $\mathbf{1 3 2 6 - 8 .}$.

3 Armstrong M D, Stave U. A study of plasma-free amino acid levels. VII. Parent-child and sibling correlations in amino acid levels. Metabolism 1973; 22: 1263-8.

4 Gerber D A, Gerber M G. Specificity of a low free serum histidine concentration for rheumatoid arthritis. J Chron Dis 1977; 33: 115-27.

5 Gerber D A. Determination of histidine in serum with o-phthaldialdehyde. Anal Biochem 1970; 34: 500-4. 